\title{
Sphingosinicella vermicomposti sp. nov., isolated from vermicompost, and emended description of the genus Sphingosinicella
}

\begin{abstract}
Correspondence
Young Ryun Chung

yrchung@gnu.ac.kr
\end{abstract}

\author{
Muhammad Yasir, ${ }^{1}$ Zubair Aslam, ${ }^{1}$ Geun Cheol Song, ${ }^{1}$ Che Ok Jeon ${ }^{2}$ \\ and Young Ryun Chung ${ }^{1}$
}

${ }^{1}$ Division of Applied Life Science (BK 21), Plant Molecular Biology \& Biotechnology Research
Center, Gyeongsang National University, Jinju 660-701, Republic of Korea

${ }^{2}$ Department of Life Sciences, Chung-Ang University, Seoul 156-756, Korea
The genus Sphingosinicella, grouped in the family Sphingomonadaceae, belongs to the Alphaproteobacteria and was proposed by Maruyama et al. (2006) with the description of a single species, Sphingosinicella microcystinivorans $\mathrm{Y}^{\mathrm{T}}{ }^{\mathrm{T}}$. Subsequently, two other species of the genus Sphingosinicella, Sphingosinicella xenopeptidilytica $3-2 \mathrm{~W} 4^{\mathrm{T}}$ and Sphingosinicella soli KSL-125 ${ }^{\mathrm{T}}$ were described (Geueke et al., 2007; Yoon et al., 2008). At the time of writing, the names of three species of the genus Sphingosinicella have been validly published.

Vermicompost (VC) is an organic manure (bio-fertilizer) produced as the vermicast by earthworms feeding on biological waste materials. Vermicomposting involves the bio-oxidation and stabilization of organic matter through the joint action of earthworms and micro-organisms (Aria

Abbreviation: VC, vermicompost.

The GenBank/EMBL/DDBJ accession number for the 16S rRNA gene sequence of strain $\mathrm{YC7378}^{\top}$ is FJ442859.

A transmission electron micrograph of strain $\mathrm{YC7378}^{\top}$, a twodimensional TLC of polar lipids from strain $\mathrm{YC} \mathrm{C} 38^{\top}$, and a phylogenetic tree based on maximum-likelihood analysis of 16S rRNA gene sequences showing the relationship of strain $\mathrm{YC7378}^{\top}$ with other related taxa are available with the online version of this paper. et al., 2002). During analysis of the bacterial community in $\mathrm{VC}$, we succeeded in isolating many novel strains by using an improved isolation method (Aslam et al., 2009). The majority of the novel bacteria isolated belonged to the phylum 'Proteobacteria'. Among them only one strain, $\mathrm{YC} 378^{\mathrm{T}}$, was related to the genus Sphingosinicella. The other novel strains were related to the members of the genera Xanthomonas and Aminobacter, while some belonged to the Betaproteobacteria. Here we report the taxonomic characterization of the newly isolated bacterial strain $\mathrm{YC} 378^{\mathrm{T}}$, which represents a novel species in the genus Sphingosinicella for which we propose the name Sphingosinicella vermicomposti sp. nov.

The vermicompost sample, prepared with paper mill and dairy sludge, was collected from a commercial farm at Masan, Korea. One gram of VC (fresh weight) was dispersed in a $100 \mathrm{ml}$ aliquot of sterile distilled water and was treated (sonication) or untreated prior to serial dilution $\left(10^{-3}-10^{-7}\right)$ (Janssen et al., 2002). A $200 \mu \mathrm{l}$ aliquot of each dilution from each sample was spread on three replicate plates of $0.08 \mathrm{~g}$ nutrient broth $\mathrm{l}^{-1}$ (Difco) supplemented with VC aqueous extract $(20 \% \mathrm{w} / \mathrm{v}, 0.2 \mu \mathrm{m}$ filter-sterilized) and $1.5 \%$ agar. The plates were incubated 
at $25{ }^{\circ} \mathrm{C}$ for 2 weeks and isolates were purified by subculturing using 1/10 strength nutrient agar (NA) media without $\mathrm{VC}$ aqueous extract. The novel strain $\mathrm{YC} 7378^{\mathrm{T}}$ was isolated and identified on the basis of 16S rRNA gene sequence analysis, chemotaxonomic and phenotypic characteristics. It was routinely cultured on half-strength R2A agar media (1.5 g R2A broth $\mathrm{l}^{-1}$ and $1.5 \%$ agar) at $30{ }^{\circ} \mathrm{C}$.

Cell morphology was observed under a Nikon light microscope at $\times 1000$ magnification and the presence of flagella was investigated using a transmission electron microscope (Hitachi, model $\mathrm{H}-600$ ) with cells grown for $24 \mathrm{~h}$ at $30{ }^{\circ} \mathrm{C}$ in half-strength $\mathrm{R} 2 \mathrm{~A}$ broth. The Gram reaction was determined by using a bioMérieux Gram staining kit according to the manufacturer's instructions. Catalase and oxidase tests were performed by using the procedures outlined by Cappuccino \& Sherman (2002). The physiological properties of strain $\mathrm{YC} 7378^{\mathrm{T}}$ and related type strains were determined according to published methods: hydrolysis of casein, aesculin, gelatin, starch, tyrosine and urea (Brown, 2007), cellulose (Hendricks et al., 1995), xylan (Broda et al., 2000) and Tweens 40 and 80 (Atlas, 1993). Enzyme activities and acid production from different carbohydrates were determined by using API ZYM and API 20E kits, respectively, at $30{ }^{\circ} \mathrm{C}$ according to the instructions of the manufacturer (bioMérieux). Assimilation of various substrates was determined by using API 20NE and Biolog GN2 Micro Plate assays as recommended by the manufacturers. Growth at different temperatures $\left(4,10,20,25,28,30,37,40\right.$ and $\left.45{ }^{\circ} \mathrm{C}\right)$ and various $\mathrm{pH}(5.0-12.0$ at intervals of $0.5 \mathrm{pH}$ units) was tested on half-strength R2A agar plates after 7 days of incubation. Growth under anaerobic conditions was determined on half-strength R2A agar plates for 7 days at $30{ }^{\circ} \mathrm{C}$ in an anaerobic GasPak jar containing an atmosphere of $\mathrm{CO}_{2}$ (GasPak System; Becton Dickinson). Salt tolerance was tested in half-strength R2A broth supplemented with 0-6\% (at $0.5 \%$ intervals) $\mathrm{NaCl}$ after 7 days of incubation at $30{ }^{\circ} \mathrm{C}$. Duplicate antibiotic-sensitivity tests were performed using filter-paper discs containing $10 \mu \mathrm{g}$ of tetracycline, gentamicin, penicillin, streptomycin or rifampicin, or $30 \mu \mathrm{g}$ of chloramphenicol, kanamycin or vancomycin. Discs were placed on half-strength R2A agar plates spread with cells of strain $\mathrm{YC} 7378^{\mathrm{T}}$ or related type strains, and plates were incubated at $30{ }^{\circ} \mathrm{C}$ for 3 days.

Strain $\mathrm{YC} 7378^{\mathrm{T}}$ was Gram-stain-negative and non-motile. Cells were rod-shaped $(0.4-0.5 \times 1.2-1.4 \mu \mathrm{m})$ (Supplementary Fig. S1, available in IJSEM Online). The strain grew well on half-strength R2A, 1/10 strength NA and $0.1 \%$ tryptic soy broth (TSB) supplemented with $1.5 \%$ agar, but did not grow on full-strength NA, TSA or MacConkey agar. Growth did not occur under anaerobic conditions. Physiological and biochemical characteristics of strain $\mathrm{YC} 7378^{\mathrm{T}}$ are summarized in the species description, and comparison of selective characteristics with those of related type strains is given in Table 1.

Cellular fatty acids of strain $\mathrm{YC} \mathrm{C} 378^{\mathrm{T}}$ and the three related type strains were analysed using colonies grown on half-
Table 1. Differential phenotypic characteristics between strain $\mathrm{YC7378}^{\top}$ and type strains of related species

Strains: 1, Sphingosinicella vermicomposti sp. nov. $\mathrm{YC} 7378^{\mathrm{T}} ; 2, S$. microcystinivorans KCTC $12019^{\mathrm{T}}$; 3, S. soli KCTC $12482^{\mathrm{T}}$; 4, S. xenopeptidilytica DSM $17130^{\mathrm{T}}$. All strains were positive for oxidase. + , Positive; -, negative; w, weak positive. Data from this study unless indicated.

\begin{tabular}{|lcccc|}
\hline Characteristic & $\mathbf{1}$ & $\mathbf{2}$ & $\mathbf{3}$ & $\mathbf{4}$ \\
\hline Nitrate reduction & - & + & - & + \\
Growth at $2.0 \% \mathrm{NaCl}$ & - & + & + & + \\
Catalase & - & + & + & + \\
Oxidase & w & + & + & + \\
Aesculin & + & - & - & - \\
Detection (by PCR) of: & & & & \\
mlrA & - & + & - & - \\
mlrB & - & + & - & - \\
puf & - & + & - & - \\
Assimilation of: & & & & \\
Tween 80 & - & + & - & + \\
Tween 40 & - & + & + & + \\
$\beta$-Hydroxybutyric acid & - & + & + & + \\
DL-Lactic acid & - & + & - & + \\
D-Alanine & + & - & - & + \\
L-Alaninamide & + & - & - & - \\
L-Ornithine & - & - & + & - \\
L-Proline & - & + & - & + \\
D-Serine & - & + & - & + \\
Trisodium citrate & - & - & - & + \\
Enzyme activity (API ZYM) & & & & \\
Valine arylamidase & + & - & + & - \\
Cystine arylamidase & + & - & - & - \\
Trypsin & + & - & - & - \\
Acid phosphatase & + & - & - & + \\
$\quad N$-acetyl- $\beta$ - & & & & \\
glucosaminidase & - & + & + & + \\
Susceptibility to antibiotics & & & & \\
Ampicillin & + & - & - & + \\
Streptomycin & - & + & + & - \\
DNA G+C content (mol\%) & 59.4 & $63.6-63.7^{\star a}$ & $65.1^{\star b}$ & $65.0^{\star c}$ \\
\hline & & & & \\
\hline
\end{tabular}

${ }^{*}$ Data from: a, Maruyama et al. (2006); b, Yoon et al. (2008); c, Geueke et al. (2007).

strength R2A for $72 \mathrm{~h}$ at $30{ }^{\circ} \mathrm{C}$. The analysis of fatty acid methyl esters was performed according to the instructions of the Microbial Identification System (MIDI; Microbial ID). Isoprenoid quinones were extracted and analysed using reverse-phase HPLC according to the method described by Komagata \& Suzuki (1987). Polyamines were analysed as described by Busse \& Auling (1988) and Busse et al. (1997). Polar lipids were extracted according to the procedure described by Minnikin et al. (1984) and were identified using two-dimensional TLC followed by spraying with the appropriate detection reagents (Minnikin et al., 1984; Komagata \& Suzuki, 1987). For the measurement of $\mathrm{G}+\mathrm{C}$ content of the chromosomal DNA, genomic DNA of 
strain $\mathrm{YC} 7378^{\mathrm{T}}$ was extracted and purified as described by Ausubel et al. (1995). It was then enzymically degraded into nucleosides and $\mathrm{G}+\mathrm{C}$ content was determined as described by Mesbah et al. (1989) using a reverse-phase HPLC.

The major cellular fatty acids of strain $\mathrm{YC} 378^{\mathrm{T}}$ comprised $\mathrm{C}_{18: 1} \omega 7 c(32.5 \%), \mathrm{C}_{16: 1} \omega 7 c$ and/or iso- $\mathrm{C}_{15: 0} \quad 2-\mathrm{OH}$ $(28.2 \%), \mathrm{C}_{14: 0} 2-\mathrm{OH}(12.2 \%)$ and $\mathrm{C}_{16: 0}(11.1 \%)$. This cellular fatty acid profile was generally similar to those of the other three species of the genus Sphingosinicella, but was distinguishable from them in terms of the content of some fatty acids, as shown in Table 2. The major respiratory quinone detected in strain $\mathrm{YC} 7378^{\mathrm{T}}$ was Q-10 and sym-homospermidine was the major polyamine. The polar lipids detected in strain $\mathrm{YC} 7378^{\mathrm{T}}$ were sphingoglycolipid, diphosphatidylglycerol, phosphatidylglycerol, phosphatidylethanolamine, phosphatidylmonomethylethanolamine and unidentified phospholipids (Supplementary Fig. S2), which showed the relatedness of strain $\mathrm{YC} 7378^{\mathrm{T}}$ to the genus Sphingosinicella (Maruyama et al., 2006). The DNA G $+C$ content of strain $\mathrm{YC} 7378^{\mathrm{T}}$ was $59.4 \mathrm{~mol} \%$.

Extraction of genomic DNA was done using a commercial genomic DNA extraction kit (Core Biosystem). The 16S rRNA gene was PCR amplified from a small amount $(1.5 \mathrm{ng})$ of purified genomic DNA by using primers $27 \mathrm{~F}$

Table 2. Cellular fatty acid composition (\%) of strain $\mathrm{YC} 7378^{\top} \mathrm{sp}$. nov. and type strains of related species

Strains: 1, Sphingosinicella vermicomposti sp. nov. YC7378 ${ }^{\mathrm{T}} ; 2, S$. microcystinivorans KCTC $12019^{\mathrm{T}}$; 3, S. soli KCTC $12482^{\mathrm{T}}$; 4, S. xenopeptidilytica DSM $17130^{\mathrm{T}}$. All data from this study. Strains were grown on half-strength R2A agar plates for $72 \mathrm{~h}$ at $30{ }^{\circ} \mathrm{C}$. -, Not detected.

\begin{tabular}{|lcccc|}
\hline Fatty acid & $\mathbf{1}$ & $\mathbf{2}$ & $\mathbf{3}$ & $\mathbf{4}$ \\
\hline Straight-chain & & & & \\
$\quad \mathrm{C}_{14: 0}$ & 1.5 & - & 1.8 & - \\
$\mathrm{C}_{16: 0}$ & 11.1 & 8.7 & 9.8 & 8.0 \\
$\mathrm{C}_{18: 0}$ & 5.5 & - & 4.1 & - \\
Unsaturated & & & & \\
$\mathrm{C}_{16: 1} \omega 5 c$ & 2.0 & 3.1 & - & 1.5 \\
$\mathrm{C}_{17: 1} \omega 6 c$ & 1.8 & 0.9 & - & 2.3 \\
$\mathrm{C}_{18: 1} \omega 7 c$ & 32.5 & 39.1 & 31.2 & 34.7 \\
$\mathrm{C}_{18: 1} \omega 9 c$ & - & - & 2.5 & - \\
Hydroxy & & & & \\
$\mathrm{C}_{14: 0} 2-\mathrm{OH}$ & 12.2 & 14.6 & 8.8 & 12.6 \\
$\mathrm{C}_{15: 0} 2-\mathrm{OH}$ & 1.1 & - & - & - \\
$\mathrm{C}_{16: 0} 2-\mathrm{OH}$ & - & - & 2.9 & - \\
iso-C & - & - & 3.7 & 1.3 \\
$11-\mathrm{M}$-Methyl $\mathrm{C}_{18: 1} \omega 7 c$ & 4.3 & 2.4 & 4.9 & 7.3 \\
Summed feature $3 *$ & 28.2 & 34.5 & 30.4 & 32.5 \\
\end{tabular}

${ }^{*}$ Summed features represent groups of two or three fatty acids that could not be separated by GLC with the MIDI system. Summed feature 3 contained $\mathrm{C}_{16: 1} \omega 7 c$ and/or iso- $\mathrm{C}_{15: 0} 2-\mathrm{OH}$. and $1492 \mathrm{R}$, and the purified PCR product was sequenced by GenoTech (Daejeon, Korea) (Lane, 1991). The 16S rRNA gene sequence was compiled using SeqMan software (DNASTAR) and the sequences of related taxa were obtained from the GenBank database. Multiple alignments were performed by using the CLUSTAL_X program (Thompson et al., 1997). Gaps were edited in the BioEdit program (Hall, 1999). Phylogenetic trees were reconstructed by using the neighbour-joining method (Saitou \& Nei, 1987) and maximum-parsimony (Fitch, 1972) in the MEGA4 program (Tamura et al., 2007) with bootstrap values based on 1000 replications (Felsenstein, 1985). A phylogenetic tree based on the maximum-likelihood algorithm was also constructed using the PHYLIP program, version 3.6 (Felsenstein, 2002). Pair-wise sequence similarity values between the novel strain $\mathrm{YC} 7378^{\mathrm{T}}$ and related taxa were computed by using a global alignment algorithm, which was implemented at the EzTaxon server (http://www. eztaxon.org/; Chun et al., 2007). The occurrence of the $m l r A, m l r B, m l r C, m l r D$ and $p u f$ genes was investigated by using primers and conditions as described by Geueke et al. (2007). The presence of the bapA gene was analysed by using primers and PCR conditions as described by Geueke et al. (2005) and the type strain S. xenopeptidilytica DSM $17130^{\mathrm{T}}$ was used as a positive control.

The entire 1314 nucleotides of the 16S rRNA gene sequence of strain $\mathrm{YC} 7378^{\mathrm{T}}$ aligned with all sequences in the MEGA4 analysis. Phylogenetic analyses of $16 \mathrm{~S}$ rRNA gene sequences showed that strain $\mathrm{YC} 7378^{\mathrm{T}}$ is closely related to species of the genus Sphingosinicella of the family Sphingomonadaceae (Fig. 1). In the phylogenetic tree, based on the neighbourjoining algorithm, strain $\mathrm{YC} 378^{\mathrm{T}}$ joined the cluster comprising the three species of the genus Sphingosinicella with $98 \%$ bootstrap support (Fig. 1). The topologies of phylogenetic trees based on the maximum-likelihood (Supplementary Fig. S3) and maximum-parsimony (data not shown) algorithms also supported the result of the neighbour-joining tree that strain $\mathrm{YC} 7378^{\mathrm{T}}$ is a novel member of the genus Sphingosinicella. Strain YC7378 exhibited 16S rRNA gene sequence similarity values of 95.7, 95.6 and $95.5 \%$ with the type strains of S. soli, S. xenopeptidilytica and $S$. microcystinivorans, respectively. Sequence similarity of less than $95.2 \%$ was observed between strain $\mathrm{YC} 7378^{\mathrm{T}}$ and the other taxa used in the phylogenetic analysis (Fig. 1). The signature nucleotides of strain $\mathrm{YC} 7378^{\mathrm{T}}$ matched with those of members of the family Sphingomonadaceae, but varied from other species of the genus Sphingosinicella as described by Geueke et al. (2007). Strain YC7378 ${ }^{\mathrm{T}}$ was the first member of the genus Sphingosinicella that showed less than $96 \%$ similarity with the other type strains of the genus. Geueke et al. (2007) identified signature nucleotides in the $16 \mathrm{~S}$ rRNA gene sequences that had more than $98 \%$ sequence similarity with each other. The low $16 \mathrm{~S}$ rRNA gene sequence similarity and intragenomic microheterogeneity in the 16S rRNA gene sequence of strain $\mathrm{YC} 7378^{\mathrm{T}}$ were probably responsible for the variation of signature nucleotides, as described by Alperi 


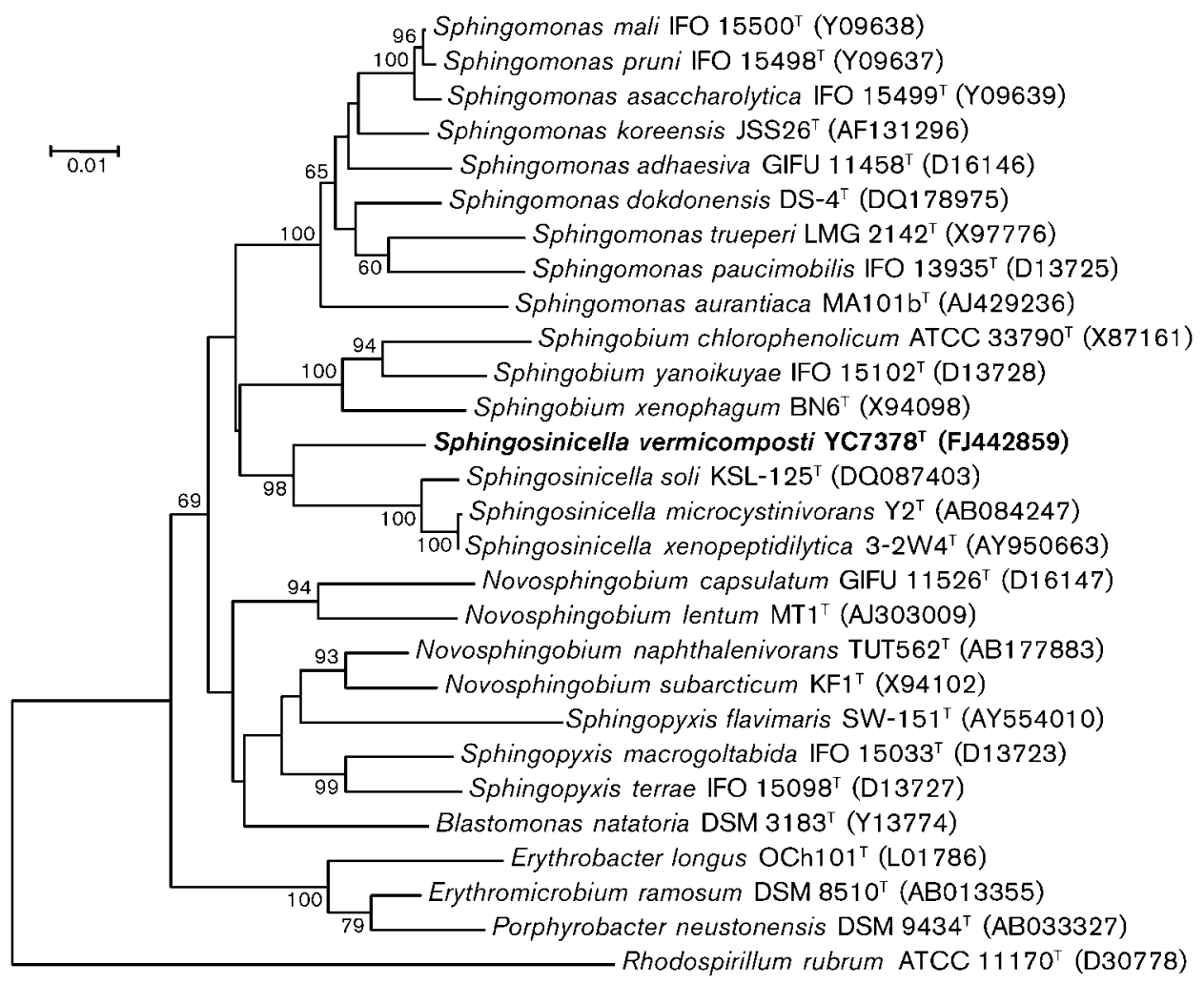

Fig. 1. Phylogenetic tree reconstructed from the comparative analysis of $16 \mathrm{~S}$ rRNA gene sequences showing the relationship of Sphingosinicella vermicomposti $\mathrm{YC} 7378^{\top} \mathrm{sp}$. nov. with other related taxa. The phylogenetic tree was reconstructed by using the neighbour-joining method and Jukes \& Cantor evolutionary distance matrix with data obtained from aligned nucleotides. Bootstrap values (expressed as percentage of 1000 replications) greater than $50 \%$ are shown at the branch points. Bar, 1 substitution per 100 nucleotide positions.

et al. (2008). The $m \operatorname{lr} A, m l r B, m l r C, m l r D, p u f$ and $b a p A$ genes were not detected in strain $\mathrm{YC} 7378^{\mathrm{T}}$.

The 16S rRNA gene sequence similarity, phylogenetic analysis and fatty acid, polyamine and polar lipid profiles clearly indicate that strain $\mathrm{YC} \mathrm{C} 38^{\mathrm{T}}$ belongs to the genus Sphingosinicella. Strain $\mathrm{YC} 7378^{\mathrm{T}}$ is distinguishable from the other species of the genus Sphingosinicella by several phenotypic characteristics (Table 1). In contrast to the related type strains, strain $\mathrm{YC} 378^{\mathrm{T}}$ is positive for cystine arylamidase and aesculin hydrolysis, but negative for catalase, $N$-acetyl- $\beta$-glucosaminidase and assimilation of $\beta$-hydroxybutyric acid. Strain YC7378 ${ }^{\mathrm{T}}$ does not exhibit the signature nucleotides of the genus Sphingosinicella. The antibiotic sensitivity, phylogenetic tree and differential phenotypic properties clearly distinguish strain $\mathrm{YC} 7378^{\mathrm{T}}$ as a member of a novel species of the genus Sphingosinicella, for which the name Sphingosinicella vermicomposti $\mathrm{YC} 378^{\mathrm{T}}$ sp. nov. is suggested.

\section{Emended description of the genus Sphingosinicella}

Characteristics are the same as given in the original description of the genus Sphingosinicella (Maruyama et al., 2006) and the amended description of the genus described by Geueke et al. (2007). However, the $\beta$-peptidyl aminopeptidase activity and the signature nucleotides in the 16S rRNA gene sequence described previously (Geueke et al., 2007) are variable from species to species within the genus Sphingosinicella.

\section{Description of Sphingosinicella vermicomposti sp. nov.}

Sphingosinicella vermicomposti (ver.mi.com.pos'ti. L. masc. n. vermis worm; N.L. neut. n. compostum compost; N.L. gen. n. vermicomposti of vermicompost, referring to the isolation of the type strain from vermicompost).

Cells are Gram-stain-negative, non-spore-forming rods (0.4$0.5 \times 1.2-1.4 \mu \mathrm{m})$. Colonies are smooth, convex, slightly sticky, circular, yellow and $0.5-1.0 \mathrm{~mm}$ in diameter after 5 days of incubation at $30{ }^{\circ} \mathrm{C}$ on half-strength $\mathrm{R} 2 \mathrm{~A}$ agar. Grows at $10-37{ }^{\circ} \mathrm{C}$ (optimum $30{ }^{\circ} \mathrm{C}$ ) and at $\mathrm{pH} 6.0$ to 11.0 (optimum $\mathrm{pH}$ 6.5-8.5). Grows in the absence of $\mathrm{NaCl}$ but not in the presence of $>1.5 \%(\mathrm{w} / \mathrm{v}) \mathrm{NaCl}$ in half-strength $\mathrm{R} 2 \mathrm{~A}$ medium. No growth under anaerobic conditions. Resistant to $10 \mu \mathrm{g}$ streptomycin but susceptible to $10 \mu \mathrm{g}$ of tetracycline, penicillin, rifampicin or gentamicin and $30 \mu \mathrm{g}$ of vancomy- 
cin, chloramphenicol or kanamycin. Weakly oxidase-positive. Can hydrolyse aesculin, but cannot hydrolyse gelatin, casein, starch, CM-cellulose, xylan, L-tyrosine, Tween 40 or Tween 80. Can use maltose, potassium gluconate, malic acid, Lalaninamide and D-alanine as a single carbon source available in API 20NE and Biolog GN2 MicroPlates. Urea is not hydrolysed. Indole and $\mathrm{H}_{2} \mathrm{~S}$ are not produced. Tryptophan deaminase is produced. Nitrate is not reduced to nitrite or nitrogen gas. Acid is not produced from different glucose sources available in the API 20E kit. In the API ZYM kit, alkaline phosphatase, esterase (C4), esterase lipase (C8), leucine arylamidase, valine arylamidase, cystine arylamidase, trypsinase, acid phosphatase, naphthol-AS-BI-phosphohydrolase and $\alpha$-glucosidase activities are present, but lipase (C14), $\alpha$-chymotrypsin, $\beta$-glucosidase, $\alpha$-galactosidase, $\beta$ galactosidase, $\beta$-glucuronidase, $N$-acetyl- $\beta$-glucosaminidase, $\alpha$-mannosidase and $\alpha$-fucosidase activities are not present. The major quinone is Q-10 and sym-homospermidine is the major polyamine. The major fatty acids are $\mathrm{C}_{18: 1} \omega 7 \mathrm{c}$, $\mathrm{C}_{16: 1} \omega 7 c$ and/or iso- $\mathrm{C}_{15: 0} 2-\mathrm{OH}, \mathrm{C}_{14: 0} 2-\mathrm{OH}$ and $\mathrm{C}_{16: 0}$. The major polar lipids are sphingoglycolipid, diphosphatidylglycerol, phosphatidylglycerol and phosphatidylethanolamine. The DNA G + C content of the type strain is $59.4 \mathrm{~mol} \%$.

The type strain, $\mathrm{YC} 7378^{\mathrm{T}}\left(=\right.$ KCTC $\left.22446^{\mathrm{T}}=\mathrm{DSM} 21593^{\mathrm{T}}\right)$, was isolated from vermicompost at Masan, Korea.

\section{Acknowledgements}

This work was supported by the Brain Korea (BK) 21 project in 20082009, under the Ministry of Education, Science and Technology, Korea.

\section{References}

Alperi, A., Figueras, M. J., Inza, I. \& Martinez-Murcia, A. J. (2008). Analysis of $16 \mathrm{~S}$ rRNA gene mutations in a subset of Aeromonas strains and their impact in species delineation. Int Microbiol 11, 185-194.

Aria, M., Monroy, F., Dominguez, J. \& Mato, S. (2002). How earthworm density affects microbial biomass and activity in pig manure. Eur J Soil Biol 38, 7-10.

Aslam, Z., Yasir, M., Jeon, C. O. \& Chung, Y. R. (2009). Lysobacter oryzae sp. nov., isolated from the rhizosphere of rice (Oryza sativa L.) managed under no-tillage practice. Int J Syst Evol Microbiol 59, 675-680.

Atlas, R. M. (1993). Handbook of Microbiological Media. Edited by L. C. Parks. Boca Raton, FL: CRC Press.

Ausubel, F. W., Brent, R., Kingston, R. E., Moore, D. D., Seidman, J. G., Smith, J. A. \& Struhl, K. (editors) (1995). Current Protocols in Molecular Biology. New York: Wiley.

Broda, D. M., Saul, D. J., Bell, R. G. \& Musgrave, D. R. (2000). Clostridium algidixylanolyticum sp. nov., a psychrotolerant, xylan-degrading, sporeforming bacterium. Int J Syst Evol Microbiol 50, 623-631.

Brown, A. E. (2007). Benson's Microbiological Applications: Laboratory Manual in General Microbiology. New York: McGraw-Hill.

Busse, H.-J. \& Auling, G. (1988). Polyamine pattern as a chemotaxonomic marker within the Proteobacteria. Syst Appl Microbiol 11, 1-8.

Busse, H. J., Bunka, S., Hensel, A. \& Lubitz, W. (1997). Discrimination of members of the family Pasteurellaceae based on polyamine patterns. Int J Syst Bacteriol 47, 698-708.
Cappuccino, J. G. \& Sherman, N. (2002). Microbiology: a Laboratory Manual, 6th edn. Menlo Park, CA: Benjamin/Cummings.

Chun, J., Lee, J. H., Jung, Y., Kim, M., Kim, S., Kim, B. K. \& Lim, Y. W. (2007). EzTaxon: a web-based tool for the identification of prokaryotes based on $16 \mathrm{~S}$ ribosomal RNA gene sequences. Int J Syst Evol Microbiol 57, 2259-2261.

Felsenstein, J. (1985). Confidence limits on phylogenies: an approach using the bootstrap. Evolution 39, 783-791.

Felsenstein, J. (2002). PHYLIP (phylogeny inference package), version 3.6a. Department of Genome Sciences, University of Washington, Seattle, USA.

Fitch, W. M. (1972). Toward defining the course of evolution: minimum change for a specific tree topology. Syst Zool 20, 406-416.

Geueke, B., Namoto, K., Seebach, D. \& Kohler, H. P. E. (2005). A novel $\beta$-peptidyl aminopeptidase (BapA) from strain 3-2W4 cleaves peptide bonds of synthetic $\beta$-tri- and $\beta$-dipeptides. J Bacteriol 187, 5910-5917.

Geueke, B., Busse, H. J., Fleischmann, T., Kämpfer, P. \& Kohler, H. P. E. (2007). Description of Sphingosinicella xenopeptidilytica sp. nov., a $\beta$-peptide-degrading species, and emended descriptions of the genus Sphingosinicella and Sphingosinicella microcystinivorans. Int J Syst Evol Microbiol 57, 107-113.

Hall, T. A. (1999). BioEdit: a user-friendly biological sequence alignment editor and analysis program for Windows 95/98/NT. Nucleic Acids Symp Ser 41, 95-98.

Hendricks, C. W., Doyle, J. D. \& Hugley, B. (1995). A new solid medium for enumerating cellulose-utilizing bacteria in soil. Appl Environ Microbiol 61, 2016-2019.

Janssen, P. H., Yates, P. S., Grinton, B. E., Taylor, P. M. \& Sait, M. (2002). Improved culturability of soil bacteria and isolation in pure culture of novel members of the divisions Acidobacteria, Actinobacteria, Proteobacteria, and Verrucomicrobia. Appl Environ Microbiol 68, 2391-2396.

Komagata, K. \& Suzuki, K. (1987). Lipid and cell-wall analysis in bacterial systematics. Methods Microbiol 19, 161-207.

Lane, D. J. (1991). 16S/23S rRNA sequencing. In Nucleic Acid Techniques in Bacterial Systematics, pp. 115-175. Edited by E. Stackebrandt \& M. Goodfellow. New York: Wiley.

Maruyama, T., Park, H. D., Ozawa, K., Tanaka, Y., Sumino, T., Hamana, K., Hiraishi, A. \& Kato, K. (2006). Sphingosinicella microcystinivorans gen. nov., sp. nov., a microcystin-degrading bacterium. Int J Syst Evol Microbiol 56, 85-89.

Mesbah, M., Premachandran, U. \& Whitman, W. B. (1989). Precise measurement of the $\mathrm{G}+\mathrm{C}$ content of deoxyribonucleic acid by highperformance liquid chromatography. Int J Syst Bacteriol 39, 159-167.

Minnikin, D. E., O'Donnell, A. G., Goodfellow, M., Alderson, G., Athalye, M., Schaal, A. \& Parlett, J. H. (1984). An integrated procedure for the extraction of bacterial isoprenoid quinones and polar lipids. J Microbiol Methods 2, 233-241.

Saitou, N. \& Nei, M. (1987). The neighbor-joining method: a new method for reconstructing phylogenetic trees. Mol Biol Evol 4, 406-425.

Tamura, K., Dudley, J., Nei, M. \& Kumar, S. (2007). MEGA4: molecular evolutionary genetics analysis (MEGA) software version 4.0. Mol Biol Evol 24, 1596-1599.

Thompson, J. D., Gibson, T. J., Plewniak, F., Jeanmougin, F. \& Higgins, D. G. (1997). The CLUSTAL_X Windows interface: flexible strategies for multiple sequence alignment aided by quality analysis tools. Nucleic Acids Res 25, 4876-4882.

Yoon, J. H., Kang, S. J., Lee, J. S., Nam, S. W., Kim, W. \& Oh, T. K. (2008). Sphingosinicella soli sp. nov., isolated from an alkaline soil in Korea. Int J Syst Evol Microbiol 58, 173-177. 